Brit. J. vener. Dis. (1956), 32, 98.

\title{
AN EXAMINATION OF KAHN'S UNIVERSAL SEROLOGICAL REACTION AS AN AID TO THE DIAGNOSIS OF SUSPECTED LATENT SYPHILIS *
}

\author{
BY \\ A. E. WILKINSON
}

From the Venereal Diseases Reference Laboratory (Medical Research Council)

Introduction

The procedure which Kahn described as the Universal Serological Reaction (Kahn, 1950) consists of a series of quantitative tests on serum, diluted in strengths of saline varying from 0 to $2 \cdot 1$ per cent., using standard Kahn antigen. An immediate reading is made after shaking and the addition of the appropriate strengths of saline, followed by further readings after 4 and 24 hours' incubation at 4 to $6^{\circ} \mathrm{C}$. The method thus combines features of the differential temperature and triple quantitative techniques previously described (Kahn, 1940, 1942), and includes a standard Kahn test. Varying "patterns" of flocculation are produced and the results are recorded in the form of graphs. An example of the pattern given by an adult male in good health is shown in Table $I$.

Serum dilutions are plotted on the vertical axis on a logarithmic scale and the salt concentrations on the horizontal axis on an arithmetic scale, separate graphs being made for the three readings. Three zones of salt concentration are distinguished

* Received for publication October 21, 1955. for descriptive purposes : Zone I, 0 to 0.3 per cent.; Zone II, 0.6 to 1.2 per cent.; Zone III 1.5 to 2.1 per cent. Table I shows that flocculation was confined to the highest dilutions in distilled water at 0 hours ; after 4 hours at refrigerator temperature it was present in low dilutions in Zone IJI, and after 24 hours it was present in all zones, including the central Zone II.

In patients with syphilis, flocculation may be present in Zone II without incubation, the series of dilutions in 0.9 per cent. saline constituting a standard quantitative Kahn test. While the titre of precipitation usually rises in Zones I and III on incubation in the cold, the titre in the 0.9 per cent. saline tends to remain fixed in syphilis, and Kahn (1951) states that only about 10 per cent. of syphilitic sera show any increase in titre in Zone II. To illustrate this, the Universal Reaction of a patient with sero-positive primary syphilis is shown in Table II.

In some patients who are thought to show nonspecific reactions with standard tests, precipitation may be present without incubation in Zone II, but may show a marked increase in titre on cold incu-

TABLE I

PRECIPITATION PATTERN GIVEN BY SERUM FROM A HEALTHY ADULT MALE

\begin{tabular}{|c|c|c|c|c|c|c|c|c|c|c|c|c|c|c|c|}
\hline \multirow{2}{*}{$\underset{\text { Serum }}{\text { Dilution }}$} & \multicolumn{15}{|c|}{ Time of Reading (hrs) } \\
\hline & \multicolumn{5}{|c|}{$\mathbf{0}$} & \multicolumn{5}{|c|}{4} & \multicolumn{5}{|c|}{24} \\
\hline $\begin{array}{c}512 \\
256 \\
128 \\
64 \\
32 \\
16 \\
8 \\
4 \\
2 \\
2 \\
\text { Neat }\end{array}$ & $\begin{array}{r}+ \\
+ \\
\ldots \\
\because \\
\because \\
\because \\
\because \\
\therefore\end{array}$ & $\begin{array}{l}. \\
\because \\
\because \\
\because \\
\because \\
\because \\
\because \\
.\end{array}$ & $\begin{array}{l}. \\
\because \\
\because \\
\because \\
\because \\
\because \\
\cdots \\
\cdots\end{array}$ & $\begin{array}{l}. \\
\ldots \\
\ldots \\
\ldots \\
\ldots \\
\ldots \\
.\end{array}$ & $\begin{array}{l}. \\
\because \\
\because \\
\because \\
\because \\
\because \\
\cdots\end{array}$ & $\begin{array}{l}+ \\
+ \\
\therefore \\
\because \\
\because \\
\therefore \\
\therefore \\
.\end{array}$ & $\begin{array}{l}. \\
\ldots \\
\ldots \\
\ldots \\
. \\
\cdots \\
.\end{array}$ & $\begin{array}{l}. \\
\ldots \\
\because \\
\ldots \\
. \\
\because \\
\cdots\end{array}$ & $\begin{array}{l}\because \\
\because \\
\because \\
\because \\
\because \\
\cdots \\
\cdots\end{array}$ & $\begin{array}{l}\because \\
\because \\
\because \\
\ddot{ } \\
\ddot{+} \\
+ \\
+\end{array}$ & $\begin{array}{l}+ \\
+ \\
\because \\
\ddot{+} \\
+ \\
+ \\
+ \\
+ \\
+\end{array}$ & $\begin{array}{c}. \\
\because \\
\because \\
\because \\
\because \\
\ddot{+} \\
+ \\
+\end{array}$ & $\begin{array}{l}\because \\
\because \\
\because \\
\because \\
\ddot{+} \\
+ \\
+\end{array}$ & $\begin{array}{l}\ldots \\
\cdots \\
\ddot{y} \\
\ddot{+} \\
+ \\
+ \\
+\end{array}$ & $\begin{array}{l}\ddot{y} \\
\ddot{y} \\
\ddot{+} \\
+ \\
+ \\
+ \\
+\end{array}$ \\
\hline$\underset{\text { (per cent.) }}{\mathrm{NaCl}}$ & 0 & 0.3 & 0.9 & 1.5 & $2 \cdot 1$ & 0 & $0 \cdot 3$ & 0.9 & $1 \cdot 5$ & $2 \cdot 1$ & 0 & 0.3 & 0.9 & 1.5 & $2 \cdot 1$ \\
\hline Zone & & I & II & & & & & II & & & & I & II & & \\
\hline
\end{tabular}


TABLE II

PRECIPITATION PATTERN GIVEN BY A PATIENT WITH SERO-POSITIVE PRIMARY SYPHILIS

\begin{tabular}{|c|c|c|c|c|c|c|c|c|c|c|c|c|c|c|c|}
\hline \multirow{2}{*}{$\begin{array}{l}\text { Serum } \\
\text { Dilution }\end{array}$} & \multicolumn{15}{|c|}{ Time of Reading (hrs) } \\
\hline & \multicolumn{5}{|c|}{0} & \multicolumn{5}{|c|}{4} & \multicolumn{5}{|c|}{24} \\
\hline $\begin{array}{r}512 \\
256 \\
128 \\
64 \\
32 \\
16 \\
8 \\
4 \\
2 \\
\text { Neat }\end{array}$ & $\begin{array}{r}\ldots \\
\cdots \\
\cdots \\
\cdots \\
+ \\
+ \\
+ \\
+ \\
+\end{array}$ & $\begin{array}{r}\cdots \\
\cdots \\
\cdots \\
\cdots \\
\cdots \\
+ \\
+ \\
++ \\
++\end{array}$ & $\begin{array}{c}. \\
\cdots \\
\cdots \\
\cdots \\
\cdots \\
+ \\
++ \\
++ \\
++\end{array}$ & $\begin{array}{r}\cdots \\
\cdots \\
\cdots \\
\cdots \\
+ \\
++ \\
++ \\
++ \\
++\end{array}$ & $\begin{array}{c}\ldots \\
\cdots \\
\cdots \\
+ \\
+ \\
++ \\
++ \\
++ \\
++ \\
+\end{array}$ & $\begin{array}{c}\cdots \\
\cdots \\
\cdots \\
\cdots \\
+ \\
+ \\
++ \\
++ \\
++\end{array}$ & $\begin{array}{c}\cdots \\
\cdots \\
\cdots \\
\cdots \\
\cdots \\
+ \\
++ \\
++ \\
++\end{array}$ & $\begin{array}{c}\cdots \\
\cdots \\
\cdots \\
\cdots \\
\cdots \\
+ \\
++ \\
++ \\
++\end{array}$ & $\begin{array}{c}\cdots \\
\cdots \\
\cdots \\
\cdots \\
+ \\
++ \\
++ \\
++ \\
++\end{array}$ & $\begin{array}{r}. \\
\cdots \\
\cdots \\
+ \\
++ \\
++ \\
++ \\
++ \\
+\end{array}$ & $\begin{array}{r}. \\
+ \\
+ \\
+ \\
+ \\
+ \\
++ \\
++ \\
++\end{array}$ & $\begin{array}{c}\cdots \\
\cdots \\
\cdots \\
\cdots \\
\ddot{+}+ \\
++ \\
++ \\
++\end{array}$ & $\begin{array}{c}\ldots \\
\cdots \\
\cdots \\
\cdots \\
\ddot{+}+ \\
++ \\
++ \\
++\end{array}$ & $\begin{array}{l}\cdots \\
\cdots \\
\cdots \\
\cdots \\
+ \\
++ \\
++ \\
++ \\
++\end{array}$ & $\begin{array}{r}0 \\
+ \\
+ \\
++ \\
++ \\
++ \\
++ \\
++ \\
++\end{array}$ \\
\hline $\begin{array}{c}\mathrm{NaCl} \\
\text { (per cent.) }\end{array}$ & 0 & 0.3 & 0.9 & $1 \cdot 5$ & $2 \cdot 1$ & 0 & 0.3 & 0.9 & $1 \cdot 5$ & $2 \cdot 1$ & 0 & $0 \cdot 3$ & 0.9 & $1 \cdot 5$ & $2 \cdot 1$ \\
\hline Zone & & I & II & & II & & & II & & II & & I & II & & II \\
\hline
\end{tabular}

TABLE III

UNIVERSAL REACTION GIVEN BY A FEMALE PATIENT WITH ATYPICAL PNEUMONIA (TPI-NEGATIVE)

\begin{tabular}{|c|c|c|c|c|c|c|c|c|c|c|c|}
\hline \multirow{2}{*}{$\begin{array}{c}\text { Serum } \\
\text { Dilution }\end{array}$} & \multicolumn{11}{|c|}{ Time of Reading (hrs) } \\
\hline & \multicolumn{3}{|c|}{0} & \multicolumn{3}{|c|}{4} & \multicolumn{5}{|c|}{24} \\
\hline $\begin{array}{l}512 \\
256\end{array}$ & $\ddot{t}+$ & . & .. & $\begin{array}{ll}++ & +\end{array}$ &. & $\begin{array}{ll}. . & +\end{array}$ & +++ & $\stackrel{+}{+}$ & $\because$ & . & $\stackrel{+}{+}$ \\
\hline 128 & $\begin{array}{ll}+ & + \\
. . & . .\end{array}$ & $\because$. & 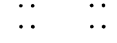 & $\begin{array}{ll}++ & + \\
. . & . .\end{array}$ & $\because$ & $\ddot{x}$ & t. &.${ }^{\top}$ & $\ddot{*}$ & $\because$ & + \\
\hline $\begin{array}{l}64 \\
32\end{array}$ & $\begin{array}{l}\because . \\
.\end{array}$ & $\because$. & $\ddot{x}$ & $\begin{array}{ll}. . & . .\end{array}$ & $\because$. & $\because$. & $\because$. & $\because$. & $\because$. & $\because$. & + \\
\hline $\begin{array}{l}16 \\
8\end{array}$ & $\begin{array}{ll}. & . .\end{array}$ & : & $\ddot{t}$ & $\ddot{+}$ & $\ddot{+}$ & $\stackrel{+}{+}$ & $\cdots+$ & $\ddot{t+}$ & $\begin{array}{r}+ \\
++\end{array}$ & $+\stackrel{+}{+}$ & $+\stackrel{+}{+}$ \\
\hline $\begin{array}{l}4 \\
2\end{array}$ & $+\quad+$ & $\ddot{t}$ & $\ddot{t}+$ & $\stackrel{+}{+}+\stackrel{+}{+}$ & $\stackrel{+}{+}$ & $\begin{array}{ll}++ & ++\end{array}$ & ++ & + & $\begin{array}{r}++ \\
+++\end{array}$ & ++ & ++ \\
\hline Neat & + & + & + & ++++ & $+t$ & $+++t$ & $+t$ & $++T$ & +++ & $++T$ & +++ \\
\hline $\begin{array}{c}\mathrm{NaCl} \\
\text { (per cent.) }\end{array}$ & $\begin{array}{ll}0 & 0.3 \\
\end{array}$ & 0.9 & $1 \cdot 5 \quad 2 \cdot 1$ & 0.3 & 0.9 & $\begin{array}{ll}1.5 & 2.1\end{array}$ & 0 & 0.3 & 0.9 & 1.5 & $2 \cdot 1$ \\
\hline Zone & $I$ & II & III & I & II & III & I & & II & & II \\
\hline
\end{tabular}

TABLE IV

UNIVERSAL REACTION GIVEN BY A FEMALE PATIENT WITH ACQUIRED HAEMOLYTIC ANAEMIA (TPI-NEGATIVE)

\begin{tabular}{|c|c|c|c|c|c|c|c|c|c|c|c|c|c|}
\hline \multirow{2}{*}{$\begin{array}{l}\text { Serum } \\
\text { Dilution }\end{array}$} & \multicolumn{13}{|c|}{ Time of Reading (hrs) } \\
\hline & \multicolumn{3}{|c|}{0} & \multicolumn{5}{|c|}{4} & \multicolumn{5}{|c|}{24} \\
\hline $\begin{array}{r}512 \\
256 \\
128 \\
64 \\
32 \\
16 \\
8 \\
4 \\
2 \\
2 \\
\text { Neat }\end{array}$ & $\begin{array}{cc}+ & . . \\
+ & \ddot{+} \\
+ & + \\
+ & + \\
+ & + \\
+ & + \\
+ & ++ \\
++ & ++ \\
++ & ++ \\
++ & ++\end{array}$ & $\begin{array}{l}\ddot{z} \\
\ddot{+} \\
+ \\
+ \\
+ \\
++ \\
++ \\
++ \\
++\end{array}$ & $\begin{array}{cc}\because & \because \\
\because & \because \\
\because & \because \\
\because & \because \\
+ & \because \\
+ & + \\
++ & + \\
++ & ++ \\
++ & ++\end{array}$ & $\begin{array}{r}+ \\
+ \\
++ \\
++ \\
+++ \\
++ \\
++ \\
+++ \\
+++ \\
+++\end{array}$ & $\begin{array}{r}. \\
\because \\
+ \\
+ \\
++ \\
+++ \\
+++ \\
+++ \\
+++ \\
+++\end{array}$ & $\begin{array}{r}. \\
\because \\
\\
+ \\
+ \\
+ \\
++ \\
+++ \\
+++ \\
+++\end{array}$ & $\begin{array}{c}\because . \\
\because: \\
\ddot{~} \\
\ddot{+} \\
++ \\
++ \\
+++ \\
+++\end{array}$ & $\begin{array}{r}\because \\
\because \\
\because \\
\because \\
+ \\
+ \\
++ \\
++ \\
++\end{array}$ & $\begin{array}{r}+ \\
+ \\
++ \\
+++ \\
++++ \\
++++ \\
++++ \\
++++ \\
++++ \\
++++\end{array}$ & $\begin{array}{r}+ \\
+ \\
+ \\
++ \\
+++ \\
+++ \\
++++ \\
++++ \\
++++ \\
++++\end{array}$ & $\begin{array}{r}\because \\
\quad . \\
+ \\
+ \\
+++ \\
+++ \\
++++ \\
++++ \\
++++ \\
++++\end{array}$ & $\begin{array}{c}\because \\
\because \\
\ddot{ } \\
++ \\
+++ \\
+++ \\
+++ \\
+++\end{array}$ & $\begin{array}{r}. \\
\because \\
\because \\
+ \\
+ \\
++ \\
+++ \\
+++ \\
+++\end{array}$ \\
\hline $\begin{array}{c}\mathrm{NaCl} \\
\text { (per cent.) }\end{array}$ & $\begin{array}{ll}0 & 0.3 \\
\end{array}$ & 0.9 & $1.5 \quad 2.1$ & 0 & 0.3 & 0.9 & 1.5 & $2 \cdot 1$ & $\mathbf{0}$ & 0.3 & 0.9 & 1.5 & $2 \cdot 1$ \\
\hline Zone & I & II & III & & I & II & III & & & I & II & III & \\
\hline
\end{tabular}

bation associated with increased precipitation in Zones I and III. Examples are shown in Tables III and IV.

In other cases there may be marked initial precipitation in Zones I or III, or both, which may encroach on Zone II without actually involving the diagnostic 0.9 per cent. saline dilutions. On incubation in the cold, the precipitation appears to
里

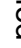

c

$\overrightarrow{0}$

" flow" into the 0.9 per cent. saline dilutions from the zones on either side, or, more rarely, from one side only. Kahn regards such patients as " potential false positive reactors" who may give actual nonspecific reactions as a result of minor infections or the use of an over-sensitive antigen in the standard Kahn test.

The Universal Reaction is easy to perform and 
needs no special equipment beyond that used by any serological laboratory carrying out standard Kahn tests. It is, however, time-consuming and requires much glassware. It was felt that it might be valuable as a verification test in the investigation of suspected non-specific STS reactions. The Treponemal Immobilization (TPI) test, with its advantages of high specificity and sensitivity in latent syphilis, is widely advocated as a means of identification of such reactions, but it is technically difficult to perform and is not generally available in Great Britain. A comparison of the performance of the Universal Reaction with the results of the TPI test was, therefore, made on 112 problem sera from patients in whom the diagnosis lay between latent syphilis and non-specific STS reactions. The results of Universal Reactions on a small number of presumed non-syphilitic patients and patients with symptomatic syphilis are also presented.

\section{Technique}

The method described by Kahn was followed with only minor modifications. Five strengths of saline were used, $0,0.3,0.9,1 \cdot 5$, and 2.1 per cent. Reagents were distributed with calibrated dropping pipettes and the results were read with the aid of a slit lamp and a $\times 6$ hand lens. The degree of precipitation was recorded as follows :

$$
\begin{aligned}
&+++ \\
&++\begin{array}{l}
\text { Complete flocculation, visible to naked eye, } \\
\text { with water-clear supernatant. }
\end{array} \\
&++\begin{array}{l}
\text { Particles easily visible with naked eye, but } \\
\text { supernatant slightly turbid. }
\end{array} \\
&+\begin{array}{l}
\text { Particles easily seen with } \times 6 \text { lens, but not } \\
\text { visible without magnification. } \\
\text { Definite discrete particles visible with } \times 6 \\
\text { lens. }
\end{array} \\
& 0 \text { No precipitation or slightly granular } \\
& \text { appearance. }
\end{aligned}
$$

The Kahn antigen used in the test was prepared in this laboratory. Different batches were used throughout the study but the sensitivity level is thought to have remained constant as each batch was compared with its predecessors by parallel testing before being passed for issue.

The TPI test was performed by the Nelson and Mayer (1949) method with the minor modifications previously described (Wilkinson, 1954). Sera were inactivated at $56^{\circ} \mathrm{C}$. for 30 minutes before the TPI test was carried out, and were stored at $-20^{\circ} \mathrm{C}$. until the Universal Reaction could be performed. Before testing they were allowed to warm up to room temperature and were then re-inactivated at $56^{\circ} \mathrm{C}$. for 10 minutes.

\section{Clinical Material}

Universal Reactions were carried out on sera from three types of patients :

(1) Presumed Non-Syphilitic Individuals. - This group consisted of sera from 34 males and four females attending a venereal diseases clinic. They showed no clinical evidence of syphilis and their STS (Wassermann reaction and Price's precipitation reaction) were negative. No venereal disease was found in 25 patients, eight had non-gonococcal urethritis, four had gonorrhoea, and one a Trichmonas vaginalis infection. In addition, two sera were examined from a healthy male laboratory worker whose STS and TPI were negative.

(2) Patients with Symptomatic Syphilis.-These comprised the following stages of the disease :

\begin{tabular}{ll|l|l}
\hline \multicolumn{2}{c|}{ Diagnosis } & No. of Patients \\
\hline Early Syphilis $\quad . \quad \ldots$ & Primary & 4 (2 untreated) \\
Late Symptomatic Syphilis & Secondary & Mucocutaneous & 7 (2 untreated) \\
& $\begin{array}{l}\text { Cardiovascular } \\
\text { Late Congenital Syphilis ... }\end{array}$ & Neurological & 11 (2 untreated) \\
\hline
\end{tabular}

Except where indicated, the patients had received treatment. All were sero-positive except for two of those with primary syphilis. The group was studied because the diagnosis had been based on clinical as well as serological evidence.

(3) Patients whose Serum Tests had been Found Positive, but who showed no Clinical Evidence of Syphilis.In these patients the diagnosis lay between latent syphilis and non-specific STS reactions. Altogether 120 sera were examined from 112 patients of this type in all of whom Universal Reactions were performed on the same

\begin{tabular}{|c|c|c|c|c|}
\hline \multicolumn{3}{|l|}{ Diagnosis } & TPI-Negative & TPI-Positive \\
\hline $\begin{array}{l}\text { ? Latent Syphilis . . } \\
\text { Pregnancy . } \\
\text { Blood Donor } \\
\text { Lupus Erythematosus } \\
\text { Leprosy . } \\
\text { Haemolytic Ánaemia } \\
\text { Miscellaneous }\end{array}$ & $\begin{array}{l}\cdots \\
\cdots \\
\cdots \\
\cdots \\
\cdots \\
\cdots\end{array}$ & $\begin{array}{l}\cdots \\
\cdots \\
\cdots \\
\cdots \\
\cdots\end{array}$ & $\begin{array}{r}6 \\
20 \\
7 \\
5 \\
4 \\
6 \\
10\end{array}$ & $\begin{array}{r}28 \\
18 \\
3 \\
- \\
-\end{array}$ \\
\hline Total & . & $\cdots$ & 58 & 54 \\
\hline
\end{tabular}
specimen of serum as that used for the TPI test. Where more than one specimen from the same patient was examined, only the results on that first tested are considered. The clinical diagnoses are summarized in Table V.

TABLE V

DIAGNOSES OF 112 PATIENTS FOUND SERO-POSITIVE ON ROUTINE TESTING AND WHO SHOWED NO CLINICAL EVIDENCE OF SYPHILIS

These sera were mainly drawn from " problem" sera sent to the V.D. Reference Laboratory for examination, and hence form a selected group. They were thought to be suitable for testing the performance of a verification test because many came from patients with conditions which are thought to cause non-specific STS reactions.

\section{Results}

Sera from Presumed Non-Syphilitic Patients.This group was examined to find what increase in precipitation in Zone II might occur with incubation in the cold in the absence of syphilis. It seemed to be a possibility that a patient's " normal" pattern 
of precipitation might influence the pattern produced should he or she acquire syphilis, and information about the normal range of precipitation was therefore desirable. Three grades could be distinguished:

(a) No precipitation in Zone II after $24 \mathrm{hrs}$ ' incubation in the cold, but moderate precipitation in Zones I or III, or both, visible after $4 \mathrm{hrs}$ and increasing after 24 hrs (24 sera).

(b) Precipitation in Zone II after 24 hrs, rarely to a high titre, with more marked precipitation in Zones I and III than in (a) (fourteen sera).

(c) Precipitation in all three zones after $4 \mathrm{hrs}$, the titres increasing after further cold incubation, more markedly in Zones I and III (one serum).

These patterns are similar to those described by Kahn (1951), who stated that more than 50 per cent. of normal individuals showed no reaction in Zone II after 24 hours' cold incubation. At this final reading, two sera were positive with undiluted serum in the 0.9 per cent. saline row, six gave a titre of two, six of four, and one of eight dilutions ; this last was the only example of marked precipitation (grade $C$ ) found in the small series examined.

Sera from Patients with Symptomatic Syphilis.The serum titres in 0.9 per cent. saline as diluent at the initial reading and after 24 hours' incubation at 4 to $6^{\circ} \mathrm{C}$. are shown in Table VI. The figures above and to the right of the diagonal represent those sera which gave the same titre after incubation, while those below and to the left of the diagonal represent sera in which the titre increased after incubation.

TABLE VI

CHANGES IN TITRE IN 0.9 PER CENT. SALINE DILUTIONS AFTER 24 HRS' COLD INCUBATION IN SERA FROM PATIENTS WITH SYMPTOMATIC SYPHILIS

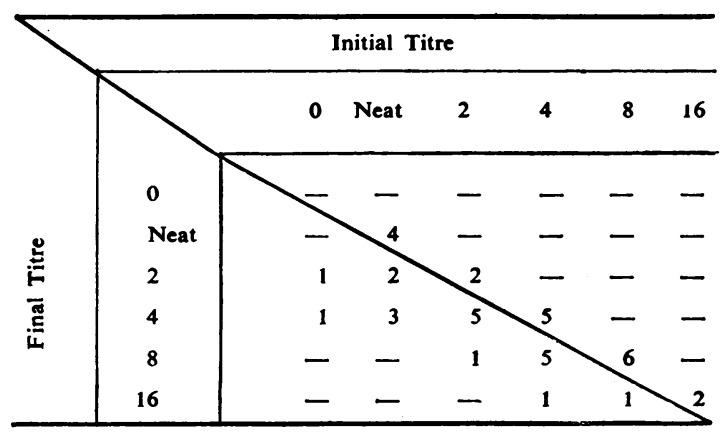

It will be seen that, while nineteen sera gave the same reading before and after incubation, thirteen showed a rise in titre of one dilution, six of two, and one of three dilutions.

Sera of the ? Latent Syphilis, ? Non-Specific Reaction Group.-These 112 patients have been divided into two classes according to the result of
TABLE VII

CHANGES IN TITRE IN 0.9 PER CENT. SALINE DILUTIONS AFTER 24 HRS' COLD INCUBATION IN THE TPI-POSITIVE PATIENTS IN THE ? LATENT SYPHILIS, ? NON-SPECIFIC REACTION GROUP

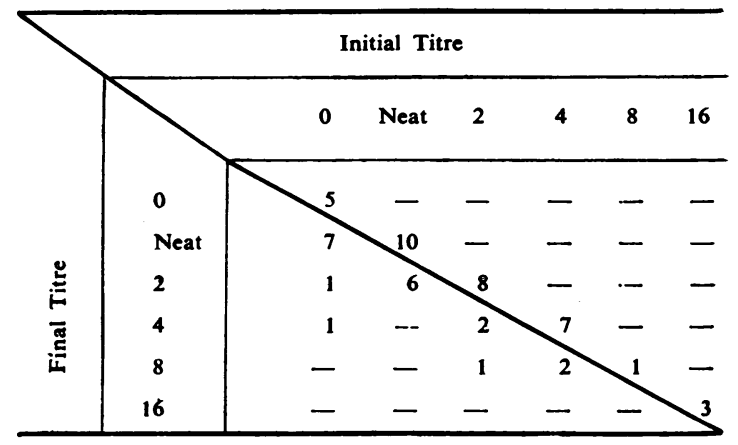

the TPI test. The changes in titre are shown in Tables VII and VIII, in which the diagonal lines separate those sera which showed no rise in titre from those in which the titre rose on cold incubation.

TABLE VIII

CHANGES IN TITRE IN 0.9 PER CENT. SALINE DILUTIONS AFTER 24 HRS' COLD INCUBATION IN THE TPI-NEGATIVE PATIENTS IN THE ? LATENT SYPHILIS, ? NON-SPECIFIC REACTION GROUP

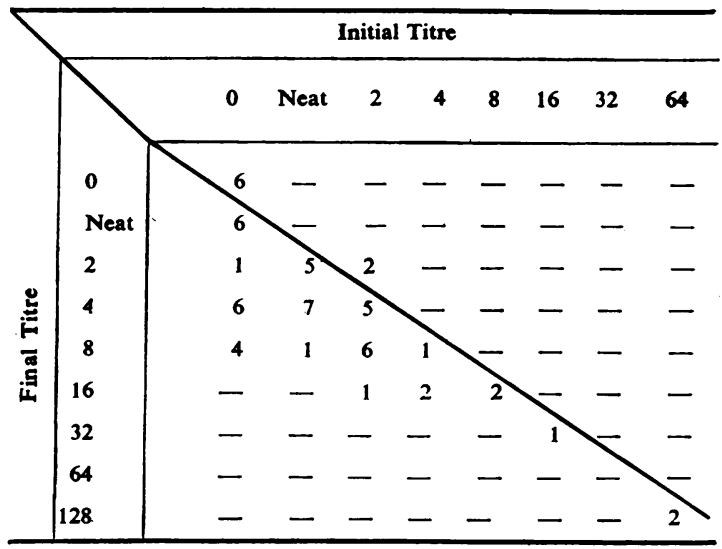

In the 54 TPI-positive sera (Table VII), 34 showed no change in titre, seventeen showed a rise of one dilution, two of two, and one of three dilutions. In contrast to this, among the 58 patients whose TPI tests were negative (Table VIII), suggesting that the STS reactions might be non-specific, only eight sera showed no change in titre after incubation, while 22 showed a rise of one dilution, sixteen of two dilutions, eight of three, and one of four dilutions.

The 112 patients who formed this group had come under observation because their STS had been 
found positive in the absence of any clinical evidence of syphilis. It will be noted that in Tables VII and VIII the Kahn test in 37 patients was initially negative, but in these patients, one or more of the other STS used (Wassermann reaction and Price's precipitation reaction) had been found positive. The whole group comprises a variety of clinical conditions which makes appraisal of the results difficult, but the patients who were found to have positive STS in association with pregnancy form a homogeneous group which is more suited to a comparison of precipitation patterns with the TPI result. These results have been extracted from Tables VII and VIII and are presented for comparison in Table IX.

TABLE IX

CHANGES IN TITRE IN 0.9 PER CENT. SALINE DILUTIONS AFTER 24 HRS COLD INCUBATION IN PATIENTS WHOSE STS REACTIONS WERE FOUND POSITIVE IN ASSOCIATION WITH PREGNANCY

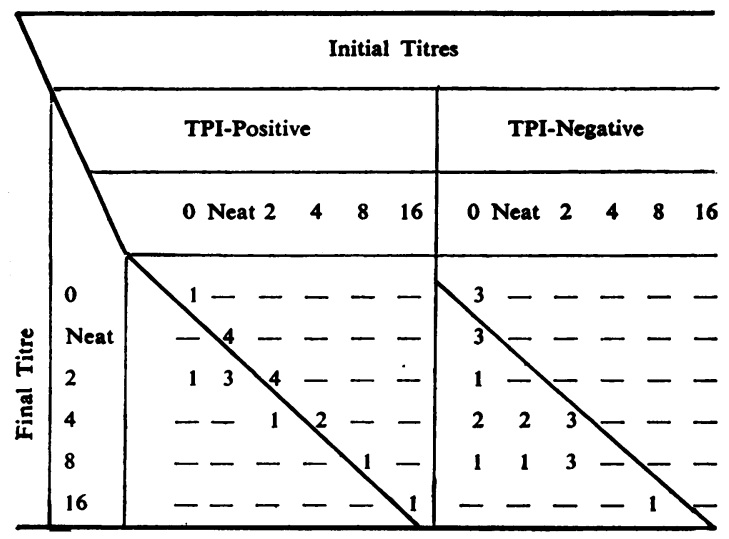

A comparison of these two groups shows that there was far less rise in titre among the patients who gave a positive TPI result. Only five out of these eighteen patients showed any rise, four of one dilution, and one of two dilutions. In marked contrast to this, seventeen out of the twenty patients, whose TPI results were negative, showed a rise in titre, six of one dilution, seven of two, three of three, and one of four dilutions. It is clear from these results that in those patients where the negative TPI result suggests that the positive STS reactions are non-specific in nature, there is a much greater tendency for increased precipitation in Zone II on cold incubation.

\section{Discussion}

As the present study of the Universal Reaction was primarily directed to its possible use as a means of investigating non-specific reactions with lipoidal antigens, attention has been concentrated on the changes in Zone II. Kahn has suggested that a feature of the syphilitic type of reaction is that precipitation in Zone II is maximal at the outset and is little influenced by cold incubation. He states that not more than 10 per cent. of syphilitic sera show a rise in titre in this zone on incubation and that these are largely confined to weakly reactive sera. This in itself would restrict the use of the Universal Reaction as a verification test because many, if not most, non-specific STS reactions are only of low titre.

Twenty out of the group of 39 patients with symptomatic syphilis showed a rise in titre on cold incubation. If "weakly reactive" sera are considered as those reactive at an arbitrary limit of two dilutions and under, thirteen out of nineteen such sera in this group showed a rise in titre on incubation against seven out of twenty where the initial titre was four dilutions or more. Many of the patients in this group had been treated and the majority of the infections were of long standing. It is not known whether treatment can affect the type of precipitation pattern in the Universal Reaction.

In the group of problem sera, the diagnosis of latent syphilis is contingent upon the positive result of the TPI test in 54 patients. Evidence in support of this contention has been presented by Wilkinson and Sequeira (1955). Of these 54 sera, 41 gave an initial titre of two dilutions or less, and, of these, seventeen showed a rise in titre on incubation. In contrast, only two of the remaining thirteen sera with an initial titre of four dilutions or more showed such a rise. These results are in agreement with Kahn's view that a rise in titre in Zone II in syphilitic sera is largely confined to weakly reactive sera. It is suggested that this may be due to the patient's normal Universal Reaction "showing through" the superimposed weak syphilitic reaction, whereas when the syphilitic reaction is strong, it may completely mask the underlying normal reaction. In this connexion, it may be pertinent that in the 39 presumed non-syphilitic individuals the final titre in Zone II after 24 hours' cold incubation was four dilutions or more in seven instances, a titre which might well modify a superimposed weak syphilitic reaction.

Altogether 58 patients in the problem sera group were thought to have given non-specific STS reactions in view of negative TPI tests. Fifty of these patients had an initial titre of two dilutions or less, 42 of these showing a rise in titre on incubation. The eight remaining patients with initial titres of four dilutions or more all showed a similar rise, but in most instances this was limited to one dilution. The tendency to increased precipitation 
TABLE X

CHANGES IN TITRE IN 0.9 PER CENT. SALINE DILUTIONS AFTER 24 HRS' COLD INCUBATION IN THE VARIOUS GROUPS OF PATIENTS STUDIED

\begin{tabular}{|c|c|c|c|c|c|c|c|}
\hline Group & $\begin{array}{l}\text { No. of } \\
\text { Patients }\end{array}$ & $\begin{array}{c}\text { Rise } \\
0\end{array}$ & in $T$ & re $(\mathrm{L}$ & Rise in Titre (Dilutions) & $\begin{array}{c}\text { ons) } \\
4\end{array}$ & \multirow{2}{*}{$\begin{array}{c}\begin{array}{c}\text { Mean } \\
\text { Rise } \\
\text { (Dilutions) }\end{array} \\
0.92 \\
\end{array}$} \\
\hline $\begin{array}{cc}\text { Presumed } & \text { Non- } \\
\text { Syphilitic } & \cdots \\
\end{array}$ & 39 & 24 & 2 & 6 & 6 & 1 & \\
\hline $\begin{array}{l}\text { Symptomatic } \\
\text { Syphilis }\end{array}$ & 39 & 19 & 13 & 6 & 1 & - & 0.72 \\
\hline $\begin{array}{l}\text { Latent Syphilis } \\
\text { ? NSR TPI-positive }\end{array}$ & 54 & 34 & 17 & 2 & 1 & 一 & 0.44 \\
\hline $\begin{array}{l}\text { ? Latent Syphilis } \\
\text { ? NSR TPI-negative }\end{array}$ & 58 & 8 & 22 & 16 & 8 & 4 & $1 \cdot 62$ \\
\hline
\end{tabular}

was thus definitely more marked than in the syphilitic patients and was more evident in the strongly reactive sera. The changes in titre in the various groups are summarized in Table $X$.

Kahn (1950) has suggested that precipitation in the three zones may be due to different antibodies, perhaps reacting with different components of the lipoidal antigen. This provides a useful hypothesis as a stimulus to further experimentation. Some evidence has been obtained from animal experiments that antibody formation apart from syphilis may affect the precipitation patterns. Unpublished observations on universal reactions carried out on rabbits before and after immunization with sheep red cells for the production of haemolytic immune bodies showed definite increases in precipitation in all zones in four out of six animals tested. There was no correlation between the changes in pattern and the haemolytic titre at the time the animals were killed. Lindau and Laurell (1952) and Laurell (1955) have recently shown by electrophoretic fractionation methods that normal (sero-negative) sera contain a reagin capable of giving positive
Wassermann and Kahn reactions. They have also presented evidence for the occurrence of more than one reagin in syphilitic sera at different stages of the disease, one of these having a similar mobility to that found in sera thought to have given nonspecific STS reactions. While these findings underline the need for further investigation of the nature of the reaction between syphilitic sera and lipoidal antigens, they also suggest that the best approach to the detection of non-specific STS reactions will be found in tests which do not employ lipoidal antigens.

\section{Summary}

Universal serological reactions were carried out on sera from 39 presumed non-syphilitic individuals, 39 patients with clinical evidence of syphilis, and on 112 "problem" sera from patients who had been investigated by means of the treponemal immobilization test (because of the finding of positive reactions with lipoidal antigens on routine testing) and showed no clinical evidence of syphilis.

Although differences in precipitation patterns were found between sera from patients with syphilis and sera from patients thought to have given nonspecific STS reactions, these differences were not sufficiently constant to allow undue reliance to be placed on the Universal Reaction as a means of distinguishing such non-specific reactions.

\section{REFERENCES}

Kahn, R. L. (1940). Arch. Derm. Syph. (Chicago), 41, 817.

(1942). Univ. Hosp. Bull., Ann Arbor, 8, 45.

(1950). "Serology with Lipid Antigen." Baillière, Tindall and Cox, London.

(1951). "An Introduction to Universal Serologic Reaction in Health and Disease." Commonwealth Fund, New York.

Laurell, A. B. (1955). Acta path. microbiol. scand., Suppl. 103.

Lindau, A., and Laurell, A. B. (1952). Ibid., Suppl. 93, p. 378.

Nelson, R. A., and Mayer, M. M. (1949). J. exp. Med., 89, 369.

Wilkinson, A. E. (1954). British Journal of Venereal Diseases, 30, 144. - , and Sequeira, P. J. L. (1955). Ibid., 31, 143. 